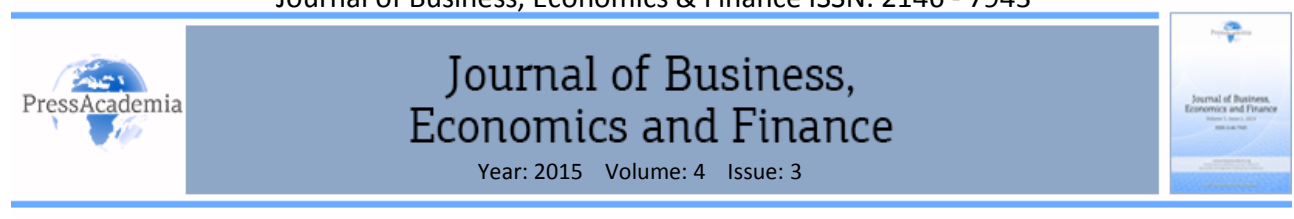

\title{
ELECTRICITY SUPPLIER SWITCHING: A CONCEPTUAL MODEL BASED ON MIGRATION THEORY
}

\section{DOI: 10.17261/Pressacademia.2015313140}

\section{Anil Savas Kilic', Nimet Uray}

1'Istanbul Technical University, Istanbul. Email: savaskilic@gmail.com

${ }^{2}$ Istanbul Technical University, Istanbul. Email: urayni@itu.edu.tr

\section{Keywords \\ Service switching, Switching factors, Pull-Push-Mooring Model, Migration theory, Utilities.}

\begin{abstract}
Electricity sector liberalization is moving forward with the purpose of efficiency, better customer service, and lower prices; however it has not fully succeeded yet, neither in Europe nor in the rest of the world. While service provider switching is an indicator of successful liberalization, it also means customer loss and acquisition from the electricity suppliers' point of view. Therefore, it has a significant importance for both the market regulator and market participants including customers and suppliers, making it a concept that should be understood thoroughly. This paper aims to build a conceptual model of electricity supplier switching behavior to be tested for a relatively neglected customer segment in the business to business market [B2B]: small and medium enterprises [SME]s. The model can also be used for business to consumer [B2C] segment because of the similar behaviors of small organizations and individuals. The model proposed in this study is mainly based on the study of Bansal et al. (2005) who adopt push, pull, and moorings [PPM] migration model to switching, using the similarities between human migration and customer switching. An extensive literature research is conducted to support and contribute to the existing PPM model and to have an extended version of it.
\end{abstract}

JEL Classification C10,G30,M10

\section{INTRODUCTION}

Liberalization is moving forward in the global energy markets with the aim of competitive market environments where the consumers could enjoy the best prices and service quality (Annala et al. 2013) with a superior operating efficiency (Payne \& Frow, 1997). However, consumers might not be willing to create a market of high mobility (Brennan, 2007) that pushes suppliers for lower prices and better performance. European Energy Regulators Group for Electricity \& Gas [ERGEG] (2010) is likeminded, announcing that the evolution of the competition is still slow. The world's situation is no different. 2011 global average of switching rates in 38 electricity markets is 7.75\% (VaasaETT, 2012b). VaasatETT (2012a) reveals that there is a little correlation between potential savings and switching levels. Consumers are failing to switch for their own good (Gamble et al., 2009). Despite "high switching rates alone should not be considered a proof of a well-functioning market" 
(Annala et al., 2013), customer activity is the first and a useful indicator to be monitored in order to assess the liberalization success (Defeuilley, 2009). It takes three sides to achieve it: Suppliers providing best offers, customers actively seeking for them, and regulatory bodies providing the best market mechanism that creates this environment. However, the customer side is still lacking, and lower prices are insufficient to motivate them. Therefore; identification of other switching factors is critical to operating an efficient market environment.

Many studies have been conducted to understand the switching reasons since 1990's in the marketing literature for a variety of service sectors such as telecommunications and banking. Studies in the electricity supply market have recently started to grow, with more attention to the household consumers (e. g. Walsh et al., 2005; Gamble et al., 2009; Annala et al., 2013; Gerpott \& Mahmudova, 2010; Hartmann \& Ibanez, 2007; Walsh et al., 2006; Ibáñez et al., 2006). B2B customers were on the researchers' radar starting with 2000's, yet they have not drawn as much attention as households, especially SMEs.

In conclusion; switching activity (1) has key importance to monitor the success of liberalization process and (2) SME segment's switching behavior in electricity supply markets has not been adequately covered by the previous literature. The purpose of this study is to propose a conceptual switching model for academicians, energy sector professionals and regulatory bodies to utilize with the purpose of having a clearer understanding of switching activity for their specific agendas. While achieving this, Bansal et al. (2005) PPM model of switching, which uses the resemblance between migration theory and service switching, is considered as the basis of the proposed model. Energy sector's status and migration theory literature is discussed prior to the extended switching model conceptualization.

\section{ELECTRICITY SUPPLY MARKET}

Liberalization of electricity markets includes privatization of public energy assets, launching competition through market structure change, and the establishment of a sector regulatory body (Pollitt, 2011). The aim of liberalization, in general, is a market structure that provides benefits to the society, transferred through lower prices and higher value (Joskow, 2008). However, the pursuit of success is still not over, as issues are reported by many studies. Turkey, a semi-liberalized energy market, is also getting its share of those issues.

\subsection{Global Market}

Discussion on the liberalization of energy markets started in the early 1980s, followed by reform commencements of several emerging and developed countries (Karan \& Kazdagli, 2011). Most of these reform plans were prepared based on the methodology called the "standard textbook model" (Larsen, 2013). The standard textbook included several key components: (a) privatization of public energy monopolies, (b) vertical unbundling of the 
value chain, (c) horizontal restructuring of the generation, (d) creating a single independent system operator, (e) the establishment of spot energy markets, (f) the development of active "demand-side" institutions, (g) the application of regulatory rules, (h) implementation of supplier of last resort structure, (i) the creation of independent regulatory bodies, and (j) transition mechanisms (Joskow, 2008). Positive results are obtained in Nordic countries, the UK, Chile, and certain Latin-American countries as the result of implementation of the textbook model (Larsen, 2013), however significant issues are experienced such as unhealthy market concentration and investment problems in Chile and Argentina (Erdogdu, 2010; Joskow, 2008). Much of Europe, Japan, and large portions of the United States [US] have not followed the textbook model and they experienced performance problems as well (Joskow, 2008; Pollitt, 2007). The examples show that the competition in electricity supply market is externally dependent on the competition in the electricity generation market, in addition to its internal dynamics. Therefore, the role and the determination of the regulatory body to provide the competition at both markets are keys to the success of the reform process.

\subsection{European Market}

EU countries have targeted to structure an integrated liberal energy market in the long term since the 1990s (Karan \& Kazdagli, 2011; Larsen, 2013). After Green Paper had been published in 1995, European Comission [EC] Directives were launched for the liberalization of electricity markets. First one was the Directive 96/92/EC and has significantly supported the internal market for electricity (Karan \& Kazdagli, 2011). The second one, Directive 2003/54/EC was adopted in 2003 setting forth that the retail market would be fully liberalized in 2007. While EC is the driving force behind the reform process in EU, the UK was the first European country and became the main driver for further developments in EU (Karan \& Kazdagli, 2011). As of 2010, the liberalization level has varied throughout Europe, from monopolies in some countries in central, east, and south eastern parts to highly competitive markets in the UK or Nordics, as shown in Figure 1.

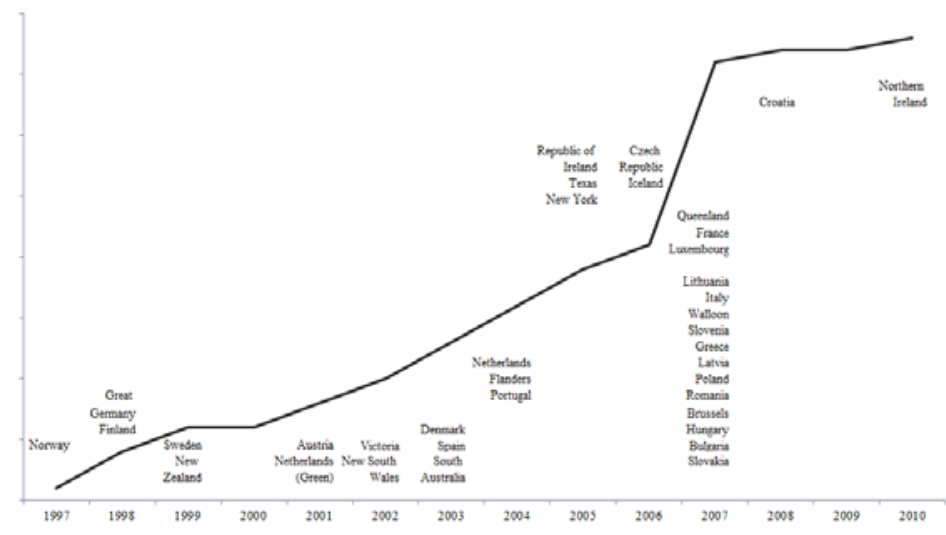

Figure 1: Full electricity retail competition timeline (Source: VaasaETT, 2012b). 
Despite the UK has had the most competitive retail market globally (Littlechild, 2014), the switching rates have started decreasing since 2008 . As of $2013,62 \%$ of customers were not able to recall their past switching activities, and $37 \%$ were still with their regional incumbents (Ofgem, 2013). Despite some problems in Nordic retail markets in the past, switching rates such as $6.7 \%$ in Denmark, 7.7\% in Finland, 9.9\% in Sweden and around $13.0 \%$ in Norway (Nordic Energy Regulators [NordREG], 2013) are the signs of a relatively well performing market.

However, the development of retail competition falls behind the expectations (Finon \& Boroumand, 2011). Also the expected results regarding competition haven't been achieved, despite the EU requirements of unbundling and liberalization (Hall et al., 2009).

\subsection{Turkish Market}

A fundamental reform was started with unbundling of the monopoly state-owned Turkish Electricity Administration [TEK] into transmission, distribution, wholesale, and generation companies mostly based on the Electricity Market Law [Law No 4628] enacted in 2001. In addition, Turkish Energy Markets Regulatory Authority [EPDK] was independently established (Ergun \& Gokmen, 2013) "in order to perform the regulatory and supervisory functions in the market" (EPDK, 2012). The Electricity Market Reform and Strategy Paper was published in March 2004, envisaging privatization of the public facilities (Akkemik, 2009), followed by a "massive privatization process" (EPDK, 2012). In the same year, free market rules were established by the Balancing and Settlement Regulation [DUY] enacted in November 2004. In 2009, Strategy Paper of the State Planning Organization was published aiming competition in energy markets to ensure efficiency and cost savings reflected to customers, in which the eligibility limit was foreseen to be zero by 2016. In 2013, a new Electricity Market Law [Law No 6446] was announced, which set forth the legal unbundling of distribution and retail operations as of December 31, 2012.

Despite the significant steps, Turkish Competition Authority [TCA] (2015) has recently identified several problems and made recommendations regarding the electricity market. According to the report; switching rates are low, which is especially a result of distribution companies' obstruction of switching. It is recommended that switching processes should be simplified. DUY amendment was announced by EPDK in 28.03.2015, and it is expected to reduce switching obstruction issues. Another important topic of the report is about the Electricity Markets Operation Company [EPIAŞ] that will take over the market operation responsibility of the Turkish Electricity Transmission Company [TEIAŞ]. It is recently formed and expected to be active in 2016, providing a more transparent market with future trading operations. TCA (2015) report also states that (1) consumer awareness should be increased, (2) regulated tariffs are still in place being a burden for the competition, (3) the theoretical market opening ratio reached $90 \%$ as of 2014 , however, the realized market opening ratio is below $40 \%$. 
Briefly, Turkey has made a significant development since the early 2000s, yet there are still problems regarding competition and customer mobility. 2016 is expected be a turning point provided that the full unbundling is in place, the eligibility limit is zero, regulatory tariff is obsolete, EPIAŞ is actively working, and results of DUY amendment are being obtained. On the eve of this new era, it is important to understand the reasons of low market activity from the point of customers' perceptions so that regulatory body and the companies can act accordingly, which will speed up the liberalization process.

\section{SERVICE SWITCHING}

Electricity supply is a service business like telecommunication, insurance and banking. Undoubtedly, the relationship is a key differentiatior of services marketing. The relationship starts with an initial decision to be in, and ends with an incident that puts switching in the customer's agenda (Jones \& Sasser, 1995). Satisfaction is known to be the earliest and most popular switching factor in the literature, keeping in mind that "... There are clearly other variables relevant to this relationship" (Jones, 1998). Service quality, switching costs, trust, price, social bonds, value, and many others have also been studied intensively. On the other hand, more elaborated conceptual models for service switching began to appear with late 1990's in the literature. Keaveney (1995), for instance, conducted an incident-based study using Critical Incident Technique [CIT], which outlines procedures for collecting observed incidents. Keaveney (1995) identified a variety of factors such as pricing, inconvenience, core service failure, service encounter failures, the response in service failure, competition, ethical problems, and involuntary switching whereas Jones and Sasser (1995) studied the effects of satisfaction and switching costs on loyalty. In addition, Zeithaml et al. (1996a) revealed service quality as an antecedent of switching intention in both B2B and B2C settings. Gremler and Brown (1996) identified interpersonal bonds as an antecedent of loyalty; alongside satisfaction and switching costs. Bansal (1997) proposed a Service Switching Model [SSM] mostly based on Keaveney (1995)'s study. Next, Bansal \& Taylor (1999) published an article by renaming the model as "The Service Provider Switching Model [SPSM]". In addition, Roos (1999) developed Switching Path Analysis Technique [SPAT] based on CIT in order to study switching as a dynamic phenomenon. The author classified the factors under "Pulling, Pushing, and Mooring [PPM]" dimensions. Bansal et al. (2005) proposed another model by adapting PPM model of migration theory in service marketing, using the similarities between them.

Due to the similarities of SMEs and individuals, we believe that the integration of migration theory with switching can enhance our knowledge on the topic. This study aims to identify the determinants of switching and support them by both service switching and migration literature.

In the case of electricity supplier switching, necessary presuppositions should be made to define switching activity accurately because there are cases when an activity, from different angles, may both look switching or staying. To overcome this issue, Lewis (2006) conducted a study for the Finnish Energy Market Authority and ERGEG. The author defines 
switching activity as "the number of switches in a given period of time" and states that switching activity can be measured based on three different approaches: the Supply Point Approach (based on total \# of supply point switches); the Customer Approach (based on total \# of customer switches), and the Energy Volume Approach (based on total volume of energy switched). The customer approach is suitable for the purpose of this study, which aims to understand motivations and experiences related to customer switching.

The real issue of defining switching arises when a customer moves house. Both Lewis and EC Directorate - General for Health \& Consumers (2010) reveal that (1) switching to the incumbent, (2) staying with the current supplier, or (3) switching to the previous occupant's supplier while moving are the simplest routes that should not be counted as switching. It is recommended that any switching activity due to moving to another location should be excluded for simplicity while conducting surveys or data mining.

\subsection{Service Switching From Migration Theory Perspective}

\subsubsection{Migration and Switching Resemblance}

Migration theory started with Ernst Ravenstein's "Laws of Migration" report published in Journal of the Statistical Society of London Society in 1885. Despite the long history, it is hard to claim that there is a consensus on a clear definition (Moon, 1995). Dyen (1956) states that migration theory "deals with the inferences of population movements and their directions" just as many other studies. Lee (1966) claims that the distance and the difficulty do not matter, as "every act of migration involves an origin, a destination, and an intervening set of obstacles". Du Toit (1990) puts it more simple as "a movement in space", emphasizing that every move, ranging from crossing the street to moving to another country, has similar attributes. Du Toit (1990) concludes to an inclusive definition: "Migration is the movement of intelligent human beings who have evaluated their condition and opted for a change that they feel will improve matters". Lee (1966) defines migration as "a relatively permanent change of usual residence" (McHugh et al., 1995). Consequently; a migration involves a relocation of the migrant for a reason and a level of obstacles during the process. It can be seen that this conception matches service switching in many aspects when migration terms are replaced with service switching terms: "service switching involves moving to another service provider for achieving better offers and a level of obstacles during the switching process."

\subsubsection{PPM Model of Migration}

The migration activity has been explained as the resultant of push and pull factors since Ravenstein (Dorigo \& Tobler, 1983). Push factors are defined as the dissatisfying attributes of the current location and pull factors are the attractive attributes of the other locations (Dorigo \& Tobler, 1983; Zengyan et al., 2009). As emphasized by Du Toit (1990), Heberle (1938) separated these factors with the push-pull theory. In 1960's, models have started to include different factors under push and pull factors (Stimson \& Minnery, 1998). Wolpert (1966) created one of the earliest behavioral migration models (Fredrickson et al., 1980). 
Lee (1966) contributed by proposing the "intervening obstacles" composite construct for PPM model. Brown and Moore (1970) and Speare (1974) expanded it bringing the households into focus as decision makers. Trlin (1976), on the other hand, proposed a model very similar with Lee (1966) in terms of factor classification: "(a) factors associated with the area of origin; (b) factors associated with the area of destination; (c) factors that act as intervening obstacles between origin and destination; and (d) personal factors". Later on Jackson (1986) updated the "obstacles" concept as "intervening variables". Longino (1992), contributed to the push-pull model with a similar concept; namely mooring variables. Moon (1995) also incorporated the mooring variables in the PPM model. Thus, all of the studies cited represent the framework of the PPM Model of switching, which refers the basis of this study and discussed in the following section.

\subsection{PPM Model of Switching in the Literature and Extension Alternatives}

"The PPM and migration theories have been applied to other contexts, such as in consumer behaviour and marketing domains" (Zengyan et al., 2009) based on the analogy between migrating and service switching. In addition to this analogy; economic views of migration approaches the migrant as "a consumer of regional amenities such as public goods" (Shields \& Shields, 1989). This view is more than an analogy approaching migration as a pure service switching.

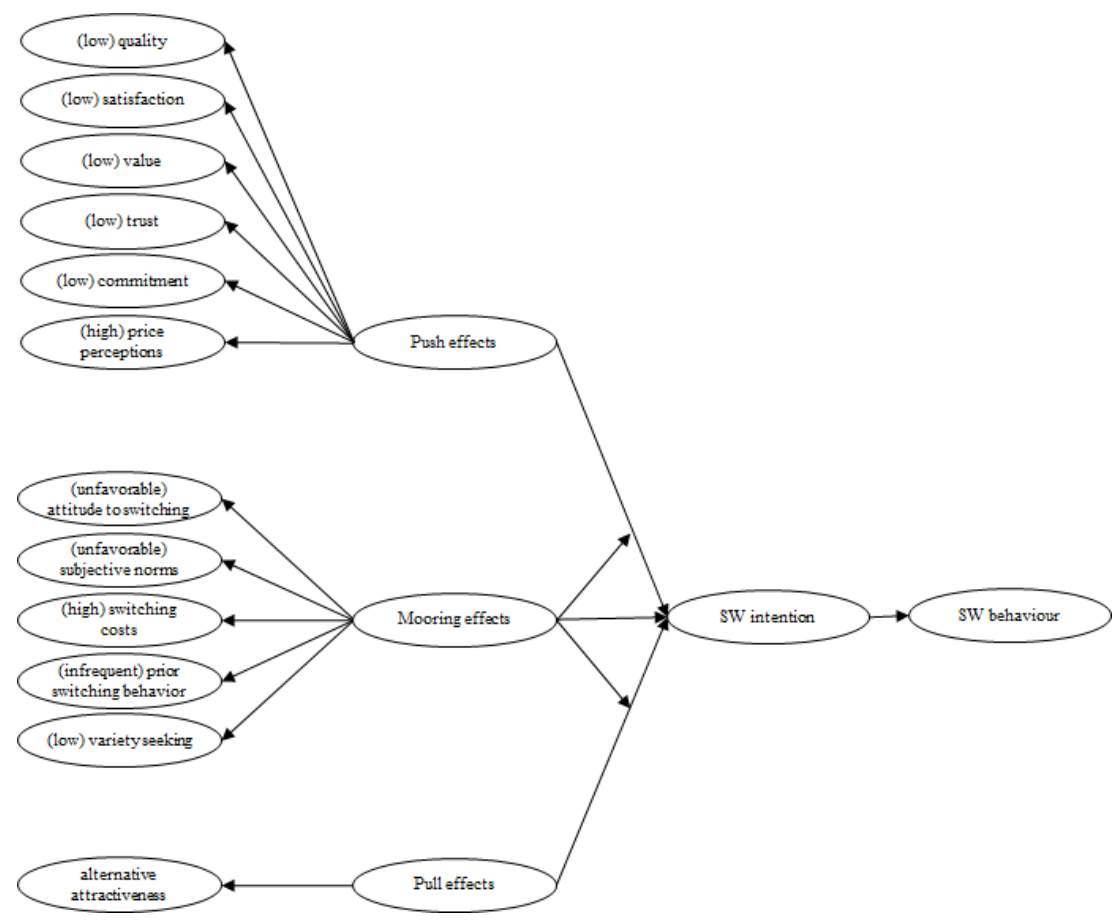

Figure 2: PPM Model of Service Switching (Bansal et al., 2005). 
The literature review revealed almost twelve studies that apply PPM model for switching in various sectors (e.g. Bansal et. al, 2005; Lui, 2005; Ek \& Söderholm, 2008; Zhang et al., 2008; Listyarini et al., 2009; Zengyan et al., 2009; Naumann et al., 2010; Hou et al., 2011; Ye \& Potter, 2011; Fu, 2011; Chiu et al., 2011; Lai et al., 2012; Zhang et al., 2012). The study of Bansal et al. (2005), which was conducted for auto-repair \& hairstyling services, is identified as the most elaborated and comprehensive one. The authors developed the model by matching PPM factors in the migration literature with the corresponding switching factors in the service switching literature (Figure 2). Yet, it is believed that additional literature support is needed for the model.

In this section, PPM model of Bansal et al. (2005) constructs are identified and discussed based on migration and service switching literature, including an electricity supply sector perspective; in order to fill the gaps for a more elaborate and electricity market specific behavioral model. Marketing literature supporting PPM model of switching are shown in tables 2 to 16 when appropriate, having all independent and dependent factors mapped to related studies. It is seen that there are a significant number of studies in addition to the ones that Bansal et al. (2005) identified. Table 1 summarizes the migration studies that support Bansal et al. (2005) model including additional studies identified by this study.

Table 1: Migration Literature Studies that Support the Use of PPM Model in Switching

\begin{tabular}{|c|c|}
\hline & Related migration literature \\
\hline$\frac{5}{\check{2}}$ & $\begin{array}{l}\text { service quality I Brown and Moore (1970), Porell (1982), Stimson and Minnery (1998), Boyle et al. } \\
\text { (1999); satisfaction I Sell and De Jong (1978), Goldstein (1977), Wolpert (1966), Brown and Moore } \\
\text { (1970), Speare (1974), Frederickson et al. (1980), Moon (1995), Stimson and Minnery (1998); value I } \\
\text { N/A; trust I N/A; commitment I N/A; price perceptions I Heberle (1938), Bogue (1969), Sell and De } \\
\text { Jong (1978), Greenwood (1985), Richmond (1988), Massey et al.(1994), Stimson and Minnery (1998) }\end{array}$ \\
\hline 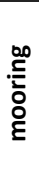 & $\begin{array}{l}\text { attitude towards switching I N/A; subjective norms I Massey et al. (1994); switching costs I Lee } \\
\text { (1966), Brown and Moore (1970), Sizer and Smith (1972), Sell and De Jong (1978), Shields and Shields } \\
\text { (1989); prior switching behavior I Lee (1966), Sell and De Jong (1978), Greenwood (1985), Du Toit } \\
\text { (1990), Greenwood et al. (1991), Massey et al. (1994), Fischer and Malmberg (2001), Stimson and } \\
\text { Minnery (1998); variety seeking I Sizer and Smith (1972), Greenwood et al. (1991) }\end{array}$ \\
\hline$\overline{\bar{z}}$ & $\begin{array}{l}\text { alternative attractiveness I Lee (1966), Dorigo and Tobler (1983), Du Toit (1990), Cadwallader } \\
\text { (1992), Moon (1995) }\end{array}$ \\
\hline
\end{tabular}

\subsubsection{Push Factors}

Service quality. Bansal et al. (2005) refer to study of Boyle et al. (1999) stating that "investigations of quality of life examine variables such as physical and economic factors associated with the origin" as an example of related migration literature. When dived deep into the migration literature, it is found that the quality of life is a commonly used migration factor. Brown and Moore (1970) include quality in one of the five main factors of selecting new residence. Porell (1982) addresses quality of life and inner metropolitan migration. Stimson and Minnery (1998) refer to quality as "strong negative attributes tended to relate to congestion, lack of facilities and general dislike of the area". Moon (1995) also discusses quality indicators of life in detail. A detailed literature study is also 
conducted for the service switching literature as shown in Table 2, which lists related studies referring quality as a factor influencing switching and the dependent / independent factors identified in the marketing literature.

Looking from the energy sector point of view, service quality components depend on how regulations define electricity suppliers' field of activity. In most of the liberalized energy markets, electricity supply companies are not responsible for electricity grid operations. In other words, electricity suppliers have limited responsibility about the electricity system (Defeuilley, 2009) and technical quality, which must be taken into account while developing the service quality items for the surveys.

Satisfaction. Satisfaction is one of the earliest switching factors studied by many researchers in marketing literature. Bansal et al. (2005) state that "the term satisfaction is used extensively in the migration literature". Sell and De Jong (1978), Goldstein (1977), Wolpert (1966), Brown and Moore (1970), Speare (1974), Frederickson et al. (1980), and Stimson and Minnery (1998) also approach satisfaction as a migration decision factor. Table 4 shows a detailed list of selected past studies that are identified by this study. It is seen that satisfaction is handled as a completely separate factor, however there are exceptions like being approached as a sub construct of relationship quality (Rauyruen \& Miller 2007) or with a narrower scope like relationship satisfaction (Caceres \& Paparoidamis, 2007).

In addition, satisfaction and service quality concepts can interfere among studies. A good example is the statement articulated by Zeithaml et al. (1996b): "The main factor determining customer satisfaction is the customers' own perceptions of service quality". Cronin et al. (2000) also emphasize this fact stating that customer satisfaction is approached as the result of a customer's perception of value that equals perceived service quality in respect to price (Hallowell, 1996). The distinction can be exhibited as follows: while satisfaction "is a rating of customer's experience with the service outcome" (Mittal and Lassar, 1998) and an "emotional reaction following a disconfirmation experience" (Oliver 1981), service quality is "a judgment made about a firm's resources and skills" (Mittal \& Lassar, 1998).

In the utilities sector, satisfaction is approached as a switching factor as well (Walsh et al., 2005). There are a number of studies that show the impact of customer satisfaction on residential customers' loyalty (Ibanez et al., 2006). There are different levels of satisfaction impacts on switching in utilities sector: "while small and medium businesses [SMB] tend to be more satisfied with their energy providers than residential consumers, SMBs are also more than twice as likely to consider switching providers" (Accenture, 2013). Walsh et al. (2005) and Naumann et al. (2010) have similar findings revealing that even satisfied customers may have intentions to switch.

Value. Bansal et al. (2005) do not refer to migration studies regarding value. However they refer to studies of Zeithaml (1988), Bansal and Taylor (1999), and Cronin et al. (2000) in 
switching literature. Table 5 shows a detailed list of selected past studies indicating value as an antecedent of behavioral intention, loyalty, repurchase intentions, and repurchase behaviour.

Misconceptions or interfering areas between value and quality and/or value and satisfaction are experienced due to the concept similarity (Cronin et al., 2000). Bansal (2007) mentions Zeithaml (1988)'s conception of value; "the trade-off between quality and sacrifice" (Bansal et al., 2005). Lam (2004) also includes a similar definition as the comparison of weighted benefits and sacrifices; which is articulated by Buzzell and Gale (1987) as "a ratio or trade-off of total benefits received to total sacrifices". Similiarly; Patterson and Spreng (1997) define value as "a ratio or trade-off of total benefits received to total sacrifices".

Trust. The model of Bansal et al. (2005) include "trust" by referring only Richmond's study from the migration literature and state that "... in migration research, a person's trust in his or her relations with others represents a push factor". In service switching context, Bansal et al. (2005) refer to studies of Morgan and Hunt (1994), Garbarino and Johnson (1999), Sharma and Patterson (2000), Hennig-Thurau et al. (2001), and Keaveney (1995). In addition to these studies, trust has been approached in the marketing literature with various constructs and listed in Table 6. The concept is named differently in the literature based on slightly different scopes: trust of supplier, trust of sales-person, brand trust, confidence, confidence benefits, reputation, ethical problems, and trust as a part of relationship quality construct.

Anderson and Narus (1990) state that "trust occurs when one party believes that the other party's actions would result in positive outcomes for itself". Briefly, it is the customer belief that the supplier will deliver as expected benefits in the long term (Lee \& Murphy, 2005). In B2B context, trust can be approached using two components, performance / credibility trust and benevolence trust (Ball et al., 2004). There are results that don't support benevolence dimension of trust in $\mathrm{B} 2 \mathrm{~B}$ settings, where companies seemed to rely more on performance. Yet, SMEs might be expected to behave more like individuals, putting more importance on benelovence.

In the energy sector; trust is generally accepted as a factor influencing energy supplier loyalty (Ibanez et al., 2006). Brand trust improvement can be realized via service integrity and brand communications (Hartmann \& Ibanez, 2007). 55\% of the customers in Australia are willing to pay more for premium products from a trusted supplier (EY, 2014). Still, there is a remarkable phenomenon in the sector: customers don't trust their energy suppliers whereas suppliers think the opposite (EY, 2011b). This situation might neutralize the impact of trust on switching; as it can lead to negative customers' doubt about being able to find a trusted electricity supplier; which in turn may invalidate the extra supplier effort to build trust. 
Commitment. Commitment is "consumer's belief that an ongoing relationship is worth investing in" (Sharma \& Patterson, 2000). It is a forward looking factor whereas satisfaction is backward looking (Gustafsson et al., 2005). There are a number of studies found in the literature that reveal commitment as an antecedent of switching (Table 7). In the literature research, it is seen that loyalty and commitment concepts interfere with each other in a portion of the studies. As emphasized by Lam et al. (2004), Oliver (1999) defines loyalty as "a buyer's overall attachment or deep commitment to a product, service, brand, or organization". Likewise, affective commitment (unlike calculative commitment) refers to an sense of belonging (Lewis and Soureli, 2006). Therefore, commitment measures should be defined to differentiate itself from loyalty accurately.

Price. It can be concluded that economic factors in migration literature and price in the service literature are similar concepts. Bogue (1969) emphasizes the criticality of economic variables in migration models. Wage difference and unemployment status between locations are widely used in migration studies such as Heberle (1938), Sell and De Jong (1978), Greenwood (1985), Richmond (1988), Massey et al. (1994), and Stimson and Minnery (1998).

Bansal et al. (2005) list studies of Colgate and Hedge (2001), Keaveney (1995), and Roos (1999) to support price as an antecedent influencing switching. There are a number of additional studies found in the literature that reveal price as an antecedent of switching (Table 10). In these studies; price is approached with similar concepts such as pricing, price changes, pricing problems, expected economic benefits, interest rate (banking sector), and service price. The dependent factors used in those studies are influencing switching attitude, switching intention, switching decision, switching behavior, loyalty, and retention.

In the energy sector, it is suggested that the price perception of the customers should be the focal point to test the price as a factor of switching, because customer perceptions are sometimes different from the reality itself: "European customers do not fully take advantage of savings opportunities that occur with switching. European households could have saved $9 \%$ on their electricity bills and $13 \%$ on their natural gas bills by switching supplier in 2011" VaasaETT (2012a). Low savings is another critical point while examining price factor. Thelander (2008) and Pakkanen and Narva (2011) reveal that electricity customers may not switch due to low saving perception. Still, Carter London Electricity had lost $30 \%$ of its sales instantly to the competitors that offered better prices shortly after liberalization (Payne \& Frow, 1997). In Australia, 1 in 8 electricity consumers missed a payment because of high prices (EY, 2014), which indicates that price is critical for a significant part of the customers. As a result, it is important to understand the customer segments' responses to price.

\subsubsection{Mooring Factors}

Attitude towards switching. Bansal et al. (2005) mention Desbarats (1983)'s study to give an example of attitudes toward migration as an influencer of the migration decision and 
Bansal and Taylor (1999)'s study as an example in the service switching literature, stating that "attitude toward switching has been associated with consumers' switching intentions".

Subjective norms. Bansal et al. (2005) refers Gardner (1981), Desbarats (1983), and Ajzen and Fishbein (1980) as studies emphasizing subjective norms as a mooring factor of migration decision. There are additional studies in this respect. For instance, Massey et al. (1994) discuss network theory and refer to migrant networks that "increase the likelihood of emigration by lowering the costs, raising the benefits, and mitigating the risks of international movement" (Massey et al., 1994). In other words; if one's immediate environment is dominated by migrants, perceived migration costs decrease.

Bansal et al. (2005) state that "inclusion of normative concerns in service-switching research is limited". Not much is found in the service switching literature regarding subjective norms. Bansal et al. (2005) mention the study of Bansal and Taylor (1999b) to support that subjective norms is an antecedent of switching.

Switching costs. Gardner (1981); Lee (1966), Sell and De Jong (1978), and De Jong and Gardner (1981) handles cost of migration as a part of mooring factors. Cost of migration is found in many other studies as a mooring factor approached as distance between locations (Sizer \& Smith, 1972; Lee, 1966), well defined streams (Lee, 1966), the expenses associated with capital investments at origin as an economic disincentive (Sell \& De Jong, 1978), cost of living differences between locations (Shields \& Shields, 1989), residential characteristics creating costs (Brown \& Moore, 1970) among many others.

Selected studies examining switching costs as an antecedent influencing switching are shown in Table 14. In these studies, switching costs concept includes independent factors such as relationship investment, investment in the relationship, time and effort, information search costs, duration of the introductory rate, apathy, negativity, inertia, and (lack of) number portability, which more or less represent switching costs.

In the energy sector; opacity of offers, excessive number of offers, difficulty level of switching, and ability of former suppliers to obstruct switching (EC Directorate - General for Health \& Consumers, 2010) are prominent factors with physical and psychological costs. A number of those factors are usually observed in the early-mid liberalization stages. Still, in a mature market like Australia, consumers experience problems searching "information relating to a prospective electricity retailer's contracts, tariffs, and policies" (EY, 2014) and find switching difficult. Residential energy consumers perceive a little more switching costs (Ibáñez et al. 2006). Fewer options are preferred by some of the customers to reduce selection costs (Brennan, 2007). As emphasized by Annala et al. (2013), difficulties of comparing tariffs have been covered by many studies (Ofgem, 2008; Pakkanen \& Narva, 2011; Ek \& Söderholm, 2008). 
Prior switching behaviour. Bansal et al. (2005) conclude that past behaviour is a mooring variable in the service switching literature, giving examples of Lattin and McAlister (1985) and Ganesh et al. (2000). However, there are a number of additional studies found that examine prior switching activity as an antecedent of switching and are shown in Table 3. The independent latent variables in those studies have a variety of names such as prior switching behavior, prior churn, relationship length, and length of business relationship, all representing similar concepts. Switching behavior, loyalty, and retention are some of the dependent latent variables of the models developed in those studies.

Variety-seeking tendencies. Bansal et al. (2005) refer to Jackson (1986) and Greenwood et al. (1991) to support variety-seeking tendencies as a factor of migration decision. In addition to these studies; Sizer and Smith (1972)'s ambition concept, similar with variety seeking, can also be correlated with migration. In terms of switching, Roos (1999)'s study is identified as an example where variation is revealed as a switching factor. White and Yanamandram (2007) also developed two dimensions for inertia; one of which is a behavioural characteristic defined as "the customer is lazy, inactive, or passive", similar to the variety-seeking construct (Colgate \& Lang, 2001) and handled as a repurchase intention factor. Table 13 summarizes mentioned studies and the related constructs.

\subsubsection{Pull Factors}

Alternative attractiveness. Bansal et al. (2005) state that; "according to the push-pull paradigm, attractive factors at the destination pull the migrant to this destination", referring studies of Moon (1995) and Dorigo and Tobler (1983) as examples of migration research. Conversely, if the alternatives are similar, the migration will less likely to happen (Lee, 1966). Attractiveness is classified by Cadwallader (1992) under physical characteristics of the destination location. Du Toit (1990) also studied attractiveness of alternatives as a factor of migration. Alternatives, even if they existed, may not be to the migrants' knowledge. This makes knowledge of alternatives an antecedent of migration (Bell, 1980).

The situation is similar in the marketing literature: Customers may choose not to switch because alternatives may be worse or not known (Colgate et al., 2007). Bansal et al. (2005) mention Bansal and Taylor (1999), Colgate and Lang (2001), Keaveney (1995), and Sharma and Patterson (2000) as prior relevant service switching literature. There are a number of additional studies referring alternative attractiveness as a factor of service switching (Table 11). Concepts used for alternative attractiveness are alternatives, attractiveness of alternatives, quality of alternative options, attraction by competitors, better service, and apathy. All of these constructs have similar measures and work in the similar logic.

Similiar concerns are valid for energy consumers who need to know if they can switch, where they can switch to, and how much saving they will gain by switching (ACER \& CEER, 2013). One of the main reasons for low mobility is that consumers "may not be aware of 
the opportunity to switch, alternative suppliers or the potential benefits of switching" (EC Directorate - General for Health \& Consumers, 2010).

\subsection{Additional Constructs for a Migration Theory Based Switching Model}

An extensive literature review both on migration theory and service switching paved the way for new constructs. Thus, it is possible to extend the model of Bansal et al. (2005) and make it more applicable for electricity supply services. These constructs are social bonds, segment focus, image, and influential triggers. The rationale for each construct is discussed in the following sections.

Social Bonds. "Family related factors including the desire to maintain or reestablish familial or other social contacts, as well as seeking to escape such relationships on the part of some people - are significant but less important push factors" (Stimson \& Minnery, 1998). In other words, poor relations with the residential environment can lead to a migration decision. Goldscheider (1971) argues that "a high degree of community attachment will inhibit migration" (Sell \& De Jong, 1978). In service switching literature, a number of studies are conducted on social bonds as an antecedent of switching under different names and shown in Table 15. In these studies, social bonds is approached using a variety of names such as inter-personal bonds, relational bonds, interpersonal relationships, emotional bonds, relationship investment, special treatment, special treatment benefits, social benefits, personnel, and personal service benefit. For instance; Roos (1999) concludes that personnel have an impact on switching behavior. Gremler and Brown (1996) state that interpersonal relationships are particularly important for loyalty. Other studies have similar findings as well. Based on its existence in both migration theory and service switching literature; the social bonds construct is proposed as a Push factor for the extended model.

Image. Migrants have an image of the target location based on their experiences; prior to information search (Brown \& Moore, 1970). For this reason, the image of the location is critical for their decision. Image is also accepted as an antecedent of switching (Lewis and Soureli, 2006; Kim \& Yoon, 2004; Aydin \& Özer, 2004). Brand building, a similar concept, is also widely discussed in the utilities sector (Hartmann \& Ibanez, 2007). Based on its existence in both migration theory and service switching literature (Table 16); the social bonds construct is proposed as one of the Push factors.

Segment Focus. The "demographic composition" of the target location is referred as a migration decision factor (Brown \& Moore, 1970), such as "an older person moving to a retirement community" (Stimson \& Minnery, 1998). Some migrants tend to choose locations where there are benefits for similar types of people like themselves. Therefore, a resemblance between "demographic composition" and "customer segment" can be easily made. The impact of customer focus and industry knowledge on switching is important in a B2B context (Schertzer, 2006). A significant part of SMEs are attracted by services 
tailored to them (Accenture, 2013). As a result of mentioned facts; segment focus construct is proposed as a new construct of Push effects for the extended model.

Influential Triggers. Switching may even occur when there is no specific search for a new supplier. The process can start with a salesperson visit where door-to-door sales are common like in Australia (Annala et al., 2010). EY (2014) reveals that $32 \%$ of the consumers switched due to a visit from a door-to-door salesperson. Clemes et al. (2010) and Roos and Gustafsson (2007) discuss the impact of influential triggers in detail, such as advertisements and salesperson visits, on switching (Table 9). As a result, influential triggers is proposed as a new construct of Pull effects in the extended model.

\section{A PROPOSED MODEL FOR SERVICE SWITCHING AND DISCUSSION}

Social bonds, segment focus, image, and influential triggers constructs are added in the extended model based on the literature research (Figure 3). Push factors are the weakest predictors as empirically tested by Bansal et al. (2015). Therefore, adding three latent variables in the Push segment is expected to strengthen the future testing of the model. Mooring is the strongest composite construct (Bansal et al., 2015) and is expected to more likely work in future tests as it is. Pull effects composite construct is in the middle in terms of predicting strength, and it is supported by a second factor, namely influential triggers.

There are critical points to be considered before applying the model for electricity markets. Putting importance on these points will increase the probability of a successful testing of the model.

First, there are constructs that show resemblance with other constructs in the model. Satisfaction and value, commitment and trust are some examples given at early sections of this study. The measures should be developed to provide an accurate factor separation in the initial data analysis stage through exploratory factor analysis. A pre-test study will enable to test how accurate the survey questions represent the variables that are assigned to them. Otherwise, there is a risk that some of the factors will merge at the initial phases of data analysis. Merging of factors does not always mean there is a problem with the survey questions; it might be valid and lead to other conclusions as well, provided that all the necessary tests are performed before conducting the surveys. 


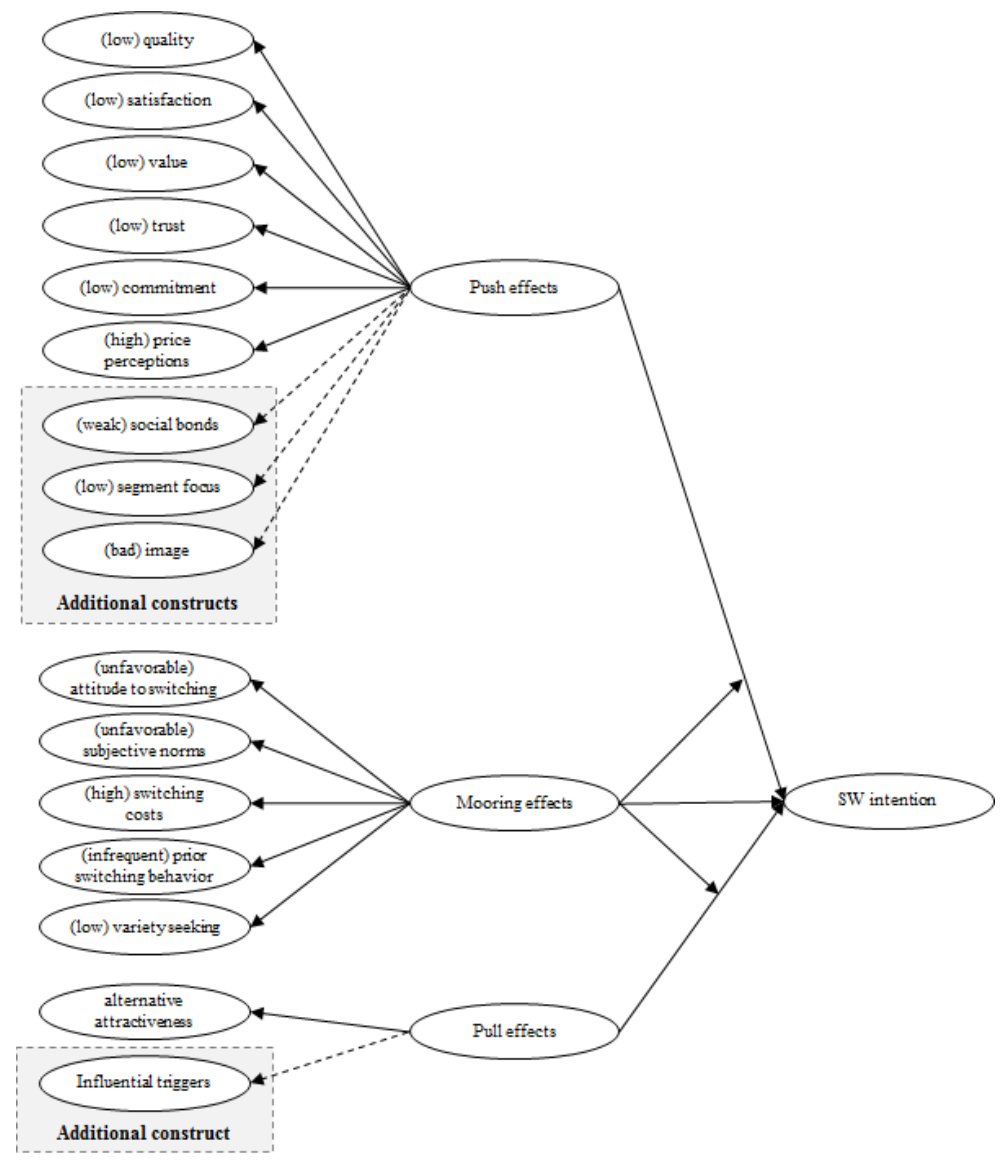

Figure 3: Proposed Migration Theory Based Conceptual Model for Switching.

Second, the original model is applied for auto-repair and hairstyling services, which represents credence and experience services (Bansal et al., 2005) and are not one to one matches with electricity supply. Before anything else, they are B2C sectors. In addition, electricity supply is a sector where purchase decision is made once and the service itself is continuous yet implicit, which makes it out of consumer's agenda until the end of the contract duration or a service incident that makes the consumer re-evaluate the supplier. Therefore, items need to be developed from the literature almost from scratch, which will increase the risk of factor merging/exclusion and/or model fit issues. This makes pretesting of survey questions more critical for the success of future studies.

Third, Bansal et al. (2005)'s model was tested in Canada. Despite boundaries are dissolving across different cultures and economies (Ger, 1999), which emerges a homogeneous global consumer culture (Cleveland \& Laroche, 2007); globalization also empowers 
national identities (Ger, 1999). This creates different consumer behaviours in different countries, especially in service sectors where relationship is an important part of the value provided by the companies. Therefore, selected country's culture and its impact on consumer behavior is another factor that will affect the results of model testing.

Fourth, auto-repair and hairstyling is a relatively competitive and unregulated environment whereas even the most competitive energy sector is a highly regulated market. Therefore, the level of liberalization at the energy market where the PPM model is being tested will directly affect the results. By default, consumers are relatively indifferent to the supplierconsumer relationship in the energy sector (EY, 2011a) because they think that electricity is a commodity which had been provided by public companies for years and hardly understand how private companies will create any extra value. In an energy market with a low liberalization level, this indifference effect will be augmented even more and most of the factors in the model will face the risk of being neutral to switching.

Fifth, customer awareness levels are expected to be low in the early stages of liberalization. The lack of awareness, as emphasized by Kruglanski and Klar (1985), is simply the state of unconsciousness (Erdelyi, 1974). "Not every single bit of confident knowledge needs to be linked in a person's awareness with other knowledge" (Kruglanski \& Klar, 1985), however "... the behavior is expected to be regulated at some level of awareness such that the relevance of new information can be noticed and taken into consideration" (Bamberg et al., 2003). Clearly, the awareness is necessary for behavioral change. However there is a long path to arrive at the behavioral stage. The theory of planned action and the theory of reasoned action literature widely agree that the behavior is influenced by the intention, the intention is influenced by the attitude, and the attitude is influenced by the belief (Madden et al., 1992). Low awareness levels might not be able to make it to the end of this path made up of belief, attitude, intention, and behavior, respectively. There is a possibility that some factors might be just strong enough, for example, to influence switching attitude instead of intention or behavior.

Sixth, the conceptual model has sixteen independent constructs and a dependent construct. The number of constructs requires a large number of items to be included in a survey study. This situation has several implications. CATI or online surveys may not be able to capture accurate data from the respondents due to their attention span limits. Face to face surveys may require higher budgets due to a large number of cases needed. Reduction of factors can be considered to overcome those limitations; however that comes with the risk of choosing the potential neutral factors and eliminating effective ones.

As a result, necessary actions should be taken in order to address the six potential issues that may be experienced in a future study. Therefore potential model fit problems will be eliminated and an effecting testing of the model will be possible. 


\section{CONCLUSION}

The PPM model of service switching is applied by a number of studies for different sectors in the literature. Yet, none of the studies fully applied the model. Therefore, there is not sufficient evidence of the applicability of the entire model to other sectors. For this reason, it is recommended to take following steps prior to its application to the energy sector in different countries: (a) Having a clear understanding of the differences between the PPM model's original country and the target country / original sector and the target energy sector (b) Collecting necessary insights about the liberalization level of the target energy sector, and clearly identify its level in respect to other liberalized energy sectors (c) Having a clear understanding of the consumers beforehand, conducting focus groups if necessary (d) Creating the items based on the literature focusing on discrimination of factors in the analysis phase. (e) Eliminating factors beforehand based on focus groups and/or previous PPM applications to fit in the limitations like budget / number of questions / number of cases.

In the light of those recommendations, an effective model of switching can be formed successfully for the energy sector, which is expected to be an important contribution to the academic literature, energy market players, and regulatory bodies.

\section{REFERENCES}

- Accenture (2013). The New Energy Consumer Handbook.

- Ajzen, I., \& Fishbein, M. (1980). Understanding attitudes and predicting social behaviour.

- $\quad$ Akkemik, K. A., \& Oğuz, F. (2011). Regulation, efficiency and equilibrium: A general equilibrium analysis of liberalization in the Turkish electricity market. Energy, 36(5), 3282-3292.

- Annala, S., Viljainen, S., \& Tuunanen, J. (2013). Rationality of supplier switching in retail electricity markets. International Journal of Energy Sector Management, 7(4), 459-477.

- $\quad$ Anderson, J. C., \& Narus, J. A. (1990). A model of distributor firm and manufacturer firm working partnerships. the Journal of Marketing, 42-58.

- Antón, C., Camarero, C., \& Carrero, M. (2007). Analysing firms' failures as determinants of consumer switching intentions: The effect of moderating factors. European Journal of Marketing, 41(1/2), 135-158.

- Aydin, S., \& Özer, G. (2004). The analysis of antecedents of customer loyalty in the Turkish mobile telecommunication market. European Journal of Marketing, 39(7/8), 910-925. 
- $\quad$ Aydin, S., Özer, G., \& Arasil, Ö. (2005). Customer loyalty and the effect of switching costs as a moderator variable: A case in the Turkish mobile phone market. Marketing Intelligence \& Planning, 23(1), 89-103.

- Babu, D. (2014). Why Kings Leave Their Kingdom-A Study on Switching Behavior of Customers and Factors Influencing This Behavioural Trait. International Journal of Management and Social Sciences Research Volume 3, No. 4, 9-13

- Bamberg, S., Ajzen, I., \& Schmidt, P. (2003). Choice of travel mode in the theory of planned behavior: The roles of past behavior, habit, and reasoned action. Basic and applied social psychology, 25(3), 175-187.

- Bansal H. S. (1997). Service switching model: A model of customer switching behavior in the services industry. A thesis in partial fulfillment of the requirements for the degree of Ph. D. in Management, Queen's University Kingston.

- $\quad$ Bansal, H. S., \& Taylor, S. F. (1999). The service provider switching model (spsm) a model of consumer switching behavior in the services industry. Journal of service Research, 2(2), 200-218.

- Bansal, H. S., Taylor, S. F., \& James, Y. S. (2005). "Migrating" to new service providers: Toward a unifying framework of consumers' switching behaviors. Journal of the Academy of Marketing Science, 33(1), 96-115.

- Beerli, A., Martin, J. D., \& Quintana, A. (2004). A model of customer loyalty in the retail banking market. European Journal of Marketing, 38(1/2), 253-275.

- Bell, M. (1980). Past mobility and spatial preferences for migration in East Africa.

- $\quad$ Bloemer, J., De Ruyter, K. O., \& Wetzels, M. (1999). Linking perceived service quality and service loyalty: a multi-dimensional perspective. European Journal of Marketing, 33(11/12), 1082-1106.

- Boyle, P. Halfacree, Keith och Robinson, Vaughan (1998). Exploring contemporary migration.

- Bogue, D. J. (1969). Principles of demography. In Principles of demography. John Wiley and sons.

- Brennan, T. J. (2007). Consumer preference not to choose: methodological and policy implications. Energy policy, 35(3), 1616-1627.

- $\quad$ Brown, L. A., \& Moore, E. G. (1970). The intra-urban migration process: a perspective. Geografiska Annaler. Series B, Human Geography, 52(1), 1-13.

- $\quad$ Buzzell, R. D., \& Gale, B. T. (1987). The PIMS principles: Linking strategy to performance. Simon and Schuster.

- Buttle, F., \& Burton, J. (2002). Does service failure influence customer loyalty?. Journal of Consumer Behaviour, 1(3), 217-227. 
- Chumpitaz Caceres, R., \& Paparoidamis, N. G. (2007). Service quality, relationship satisfaction, trust, commitment and business-to-business loyalty. European journal of marketing, 41(7/8), 836-867.

- Cadwallader, M. T. (1992). Migration and residential mobility: Macro and micro approaches. Univ of Wisconsin Press.

- Chiu, H. C., Hsieh, Y. C., Li, Y. C., \& Lee, M. (2005). Relationship marketing and consumer switching behavior. Journal of Business Research, 58(12), 1681-1689.

- Clemes, M. D., Gan, C., \& Zhang, D. (2010). Customer switching behaviour in the Chinese retail banking industry. International Journal of Bank Marketing, 28(7), 519-546.

- $\quad$ Cleveland, M., \& Laroche, M. (2007). Acculturaton to the global consumer culture: Scale development and research paradigm. Journal of business research, 60(3), 249-259.

- $\quad$ Colgate, M., \& Lang, B. (2001). Switching barriers in consumer markets: an investigation of the financial services industry. Journal of consumer marketing, 18(4), 332-347.

- Colgate, M., Tong, V. T. U., Lee, C. K. C., \& Farley, J. U. (2007). Back from the brink: Why customers stay. Journal of Service Research, 9(3), 211-228.

- Colgate, M., \& Hedge, R. (2001). An investigation into the switching process in retail banking services. International Journal of Bank Marketing, 19(5), 201-212.

- Cronin Jr, J. J., \& Taylor, S. A. (1992). Measuring service quality: a reexamination and extension. The journal of marketing, 55-68.

- Cronin, J. J., Brady, M. K., \& Hult, G. T. M. (2000). Assessing the effects of quality, value, and customer satisfaction on consumer behavioral intentions in service environments. Journal of retailing, 76(2), 193-218.

- $\quad$ De Ruyter, K., Wetzels, M., \& Bloemer, J. (1998). On the relationship between perceived service quality, service loyalty and switching costs. International Journal of Service Industry Management, 9(5), 436-453.

- Defeuilley, C. (2009). Retail competition in electricity markets. Energy Policy, 37(2), 377-386.

- Desbarats, J. (1983). Spatial choice and constraints on behavior. Annals of the Association of American Geographers, 73(3), 340-357.

- Doney, P. M., \& Cannon, J. P. (1997). An examination of the nature of trust in buyer-seller relationships. the Journal of Marketing, 35-51.

- Dorigo, G., \& Tobler, W. (1983). Push-Pull Migration Laws. Annals of the Association of American Geographers, 73(1), 1-17. 
- Du Toit, B. M. (1990). Rural-urban Migration with Special Reference to the Third World: Theoretical and Empirical Perspectives. Human Organization, 49(4), 305319.

- Dyen, I. (1956). Language distribution and migration theory. Language, 611-626.

- Erdelyi, M. H. (1974). A new look at the new look: perceptual defense and vigilance. Psychological review, 81(1), 1.

- Erdogdu, E. (2010). Electricity Market Reform: Lessons for Developing Countries.

- Ergun and Gokmen (2013). Electricity regulation in Turkey: overview. MultiJurisdictional Guide 2013, Energy and Natural Resources.

- Eshghi, A., Haughton, D., \& Topi, H. (2007). Determinants of customer loyalty in the wireless telecommunications industry. Telecommunications policy, 31(2), 93106.

- $\quad$ European Comission Directorate - General for Health \& Consumers (2010). Functioning of retail electricity markets for consumers in the European Union Final Report. ECME Consortium.

- European Energy Regulators Group for Electricity \& Gas (2010). ERGEG 2010 Status Review of the Liberalisation and Implementation of the Energy Regulatory Framework. Bruxelles.

- $\quad$ EY (2011a). The rise of smart customers - What consumers think.

- $\quad E Y(2011 b)$. The rise of smart customers - What sector thinks.

- EY (2014). Voice of the customer is getting louder.

- Finon, D., \& Boroumand, R. H. (2011). Electricity retailers' competition: From survival strategies to oligopolistic behavior.

- Fischer, P. A., \& Malmberg, G. (2001). Settled people don't move: On life course and (im-) mobility in Sweden. International Journal of Population Geography, 7(5), 357-371.

- $\quad$ Fredrickson, C., Heaton, T. B., Fuguitt, G. V., \& Zuiches, J. J. (1980). Residential preferences in a model of migration intentions. Population and Environment, 3(34), 280-297.

- Fu, J. R. (2011). Understanding career commitment of IT professionals: Perspectives of push-pull-mooring framework and investment model. International Journal of Information Management, 31(3), 279-293.

- Gamble, A., Juliusson, E. A., \& Gärling, T. (2009). Consumer attitudes towards switching supplier in three deregulated markets. The Journal of Socio-Economics, 38(5), 814-819.

- $\quad$ Ganesh, J., Arnold, M. J., \& Reynolds, K. E. (2000). Understanding the customer base of service providers: an examination of the differences between switchers and stayers. Journal of marketing, 64(3), 65-87. 
- Garbarino, E., \& Johnson, M. S. (1999). The different roles of satisfaction, trust, and commitment in customer relationships. the Journal of Marketing, 70-87.

- Gardner, R. W. (1981). Macrolevel influences on the migration decision process.

- Ger, G. (1999). Localizing in the global village: Local firms competing in global markets. California Management Review, 41(4), 64.

- Gerpott, T. J., \& Mahmudova, I. (2010). Determinants of green electricity adoption among residential customers in Germany. International Journal of Consumer Studies, 34(4), 464-473.

- Gerrard, P., \& Barton Cunningham, J. (2004). Consumer switching behavior in the Asian banking market. Journal of Services Marketing, 18(3), 215-223.

- Goldscheider, C. (1971). Population, modernization, and social structure.

- Goldstein, S. (1976). Facets of redistribution: research challenges and opportunities. Demography, 13(4), 423-434.

- Greenwood, M. J. (1985). Human migration: Theory, models, and empirical studies. Journal of regional Science, 25(4), 521-544.

- Greenwood, M. J., Mueser, P. R., Plane, D. A., \& Schlottmann, A. M. (1991). New directions in migration research. The Annals of Regional Science, 25(4), 237-270.

- Gremler, D. D., \& Brown, S. W. (1996). Service loyalty: its nature, importance, and implications. Advancing service quality: A global perspective, 171-180.

- Gustafsson, A., Johnson, M. D., \& Roos, I. (2005). The effects of customer satisfaction, relationship commitment dimensions, and triggers on customer retention. Journal of marketing, 69(4), 210-218.

- Hall, D., Thomas, S., \& Corral, V. (2009). Global experience with electricity liberalisation.

- Hallowell, R. (1996). The relationships of customer satisfaction, customer loyalty, and profitability: an empirical study. International journal of service industry management, 7(4), 27-42.

- Hartmann, P., \& Ibáñez, V. A. (2007). Managing customer loyalty in liberalized residential energy markets: The impact of energy branding. Energy Policy, 35(4), 2661-2672.

- Heberle, R. (1938). The Causes of Rural-Urban Migration a Survey of German Theories. American Journal of Sociology, 932-950.

- Hennig-Thurau, T., Langer, M. F., \& Hansen, U. (2001). Modeling and Managing Student Loyalty An Approach Based on the Concept of Relationship Quality. Journal of Service Research, 3(4), 331-344.

- Hess, M., \& Enric Ricart, J. (2003). Managing customer switching costs: a framework for competing in the networked environment. Management Research: Journal of the Iberoamerican Academy of Management, 1(1), 93-110. 
- Hou, A. C., Chern, C. C., Chen, H. G., \& Chen, Y. C. (2011). 'Migrating to a new virtual world': Exploring MMORPG switching through human migration theory. Computers in Human Behavior, 27(5), 1892-1903.

- Ibáñez, V. A., Hartmann, P., \& Calvo, P. Z. (2006). Antecedents of customer loyalty in residential energy markets: Service quality, satisfaction, trust and switching costs. The Service Industries Journal, 26(6), 633-650.

- Jackson John A. (1986). Migration In Aspects of Modern Sociology: Social Processes. London and New York: Longman.

- Jones, M. A. (1998). Satisfaction and repurchase intentions in the service industry: the moderating influence of switching barriers.

- Jones, T. O., \& Sasser, W. E. (1995). Why satisfied customers defect. Harvard Business Review, 73(6), 88.

- Joskow, P. (2008). Lessons learned from electricity market liberalization. The Energy Journal, 29(2), 9-42.

- Karan, M. B., \& Kazdağli, H. (2011). The development of energy markets in Europe. In Financial Aspects in Energy (pp. 11-32). Springer Berlin Heidelberg.

- Keaveney, S. M. (1995). Customer switching behavior in service industries: An exploratory study. The Journal of Marketing, 71-82.

- Keaveney, S. M., \& Parthasarathy, M. (2001). Customer switching behavior in online services: An exploratory study of the role of selected attitudinal, behavioral, and demographic factors. Journal of the academy of marketing science, 29(4), 374-390.

- $\quad$ Kim, H. S., \& Yoon, C. H. (2004). Determinants of subscriber churn and customer loyalty in the Korean mobile telephony market. Telecommunications Policy, 28(9), 751-765.

- $\quad$ Kim, H. W., Gupta, S., \& Lee, S. H. (2013). Examining the Effect of Online Switching Cost on Customers' Willingness to Pay More. Asia Pacific Journal of Information Systems, 23(1), 21-43.

- Kim J. (2008). An empirical analysis of consumers' switching decisions in the mobile service industry. A dissertation submitted in partial fulfillment of the requirements for the degree of Doctor of Philosophy (Economics) at the University of Wisconsin-Madison.

- Kim, M. K., Park, M. C., \& Jeong, D. H. (2004). The effects of customer satisfaction and switching barrier on customer loyalty in Korean mobile telecommunication services. Telecommunications policy, 28(2), 145-159.

- Kruglanski, A. W., \& Klar, Y. (1985). Knowing what to do: on the epistemology of actions. In Action Control (pp. 41-60). Springer Berlin Heidelberg. 
- Jones, M. A., Mothersbaugh, D. L., \& Beatty, S. E. (2000). Switching barriers and repurchase intentions in services. Journal of retailing, 76(2), 259-274.

- Lai, F., Griffin, M., \& Babin, B. J. (2009). How quality, value, image, and satisfaction create loyalty at a Chinese telecom. Journal of Business Research, 62(10), 980-986.

- $\quad$ Lai, J. Y., Debbarma, S., \& Ulhas, K. R. (2012). An empirical study of consumer switching behaviour towards mobile shopping: a Push-Pull-Mooring model. International Journal of Mobile Communications, 10(4), 386-404.

- Lam, R., \& Burton, S. (2006). SME banking loyalty (and disloyalty): a qualitative study in Hong Kong. International Journal of Bank Marketing, 24(1), 37-52.

- $\quad$ Lam, R., Burton, S., \& Lo, H. P. (2009). Customer tradeoffs between key determinants of SME banking loyalty. International journal of bank marketing, 27(6), 428-445.

- Lam, S. Y., Shankar, V., Erramilli, M. K., \& Murthy, B. (2004). Customer value, satisfaction, loyalty, and switching costs: an illustration from a business-tobusiness service context. Journal of the Academy of Marketing Science, 32(3), 293-311.

- Larsen, F. R. (2013). Implications of electricity sector liberalization on marketing decisions.

- Lee, E. S. (1966). A theory of migration. Demography, 3(1), 47-57.

- Lee, R., \& Murphy, J. (2005). From loyalty to switching: exploring the determinants in the transition. In Proceedings of the Australia and New Zealand Marketing Academy Conference, Perth, Australia (pp. 196-203).

- Lewis, B. R., \& Soureli, M. (2006). The antecedents of consumer loyalty in retail banking. Journal of consumer Behaviour, 5(1), 15-31.

- $\quad$ Li, X. R., \& Petrick, J. F. (2008). Examining the antecedents of brand loyalty from an investment model perspective. Journal of Travel Research, 47(1), 25-34.

- Littlechild, S. (2014). Promoting or restricting competition?: Regulation of the UK retail residential energy market since 2008 (No. 1441). Faculty of Economics, University of Cambridge.

- Madden, T. J., Ellen, P. S., \& Ajzen, I. (1992). A comparison of the theory of planned behavior and the theory of reasoned action. Personality and social psychology Bulletin, 18(1), 3-9.

- Massey, D. S., Arango, J., Hugo, G., Kouaouci, A., Pellegrino, A., \& Taylor, J. E. (1994). An evaluation of international migration theory: the North American case. Population and development Review, 699-751. 
- $\quad$ Matthews, C. D., Moore, C. I., \& Wright, M. (2008). Why not switch? Switching costs and switching likelihood. In 13th Finsia and Melbourne Centre for Financial Studies Banking and Finance Conference, Melbourne, Australia (pp. 29-30).

- McHugh, K. E., Hogan, T. D., \& Happel, S. K. (1995). Multiple Residence and Cyclical Migration: A Life Course Perspective. The Professional Geographer, 47(3), 251-267.

- Mittal, B., \& Lassar, W. M. (1998). Why do customers switch? The dynamics of satisfaction versus loyalty. Journal of services marketing, 12(3), 177-194.

- Molinari, L. K., Abratt, R., \& Dion, P. (2008). Satisfaction, quality and value and effects on repurchase and positive word-of-mouth behavioral intentions in a B2B services context. Journal of Services Marketing, 22(5), 363-373.

- Moon, B. (1995). Paradigms in migration research: exploring" moorings" as a schema. Progress in Human Geography, 19(4), 504-524.

- Morgan, R. M., \& Hunt, S. D. (1994). The commitment-trust theory of relationship marketing. the journal of marketing, 20-38.

- Naumann, E., Haverila, M., Sajid Khan, M., \& Williams, P. (2010). Understanding the causes of defection among satisfied B2B service customers. Journal of Marketing Management, 26(9-10), 878-900.

- $\quad$ Nordic Energy Regulators (2013). Nordic Market report 2013 - 6/2013.

- Ofgem (2013). State of the Market Assessment.

- Ofgem (2008). Energy Supply Probe - Initial Findings Report.

- Oliver, R. L. (1999). Whence consumer loyalty?. the Journal of Marketing, 33-44.

- Pakkanen, M. and Narva, T. (2011). Functioning of the Electricity Market in Finland - The Customer's Point of View. Report, Full Version, SGEM WP 5.

- Payne, A., \& Frow, P. (1997). Relationship marketing: key issues for the utilities sector. Journal of Marketing Management, 13(5), 463-477.

- Pollitt, M. (2007). Liberalisation and Regulation in Electricity Systems: How can we get the balance right?.

- Pollitt, M. (2011). Energy Liberalisation in Historical Context. Economic Policy.

- $\quad$ Porell, F. W. (1982). INTERMETROPOLITAN MIGRATION AND QUALITY OF LIFE. Journal of Regional Science, 22(2), 137-158.

- $\quad$ Rauyruen, P., \& Miller, K. E. (2007). Relationship quality as a predictor of B2B customer loyalty. Journal of business research, 60(1), 21-31.

- Ravenstein, E. G. (1885). The laws of migration. Journal of the Statistical Society of London, 167-235.

- Turkish Competition Authority (2015). Elektrik Toptan Satış ve Perakende Satış Sektör Araştırması. 
- Richmond, A. H. (1988). Sociological theories of international migration: the case of refugees. Current Sociology, 36(2), 7-25.

- Roos, I. (1999). Switching processes in customer relationships. Journal of Service Research, 2(1), 68-85.

- $\quad$ Roos, I., \& Gustafsson, A. (2007). Understanding frequent switching patterns. Journal of Service Research, 10(1), 93-108.

- $\quad$ Rust, R. T., \& Zahorik, A. J. (1993). Customer satisfaction, customer retention, and market share. Journal of retailing, 69(2), 193-215.

- Schertzer S. M. B. (2006). The Influence of Quality on Business-to-Business (B2B). A dissertation submitted as part of the requirements for the degree of doctorate of philosophy in Business Administration (Marketing).

- $\quad$ Sell, R. R., \& DeJong, G. F. (1978). Toward a motivational theory of migration decision making. Journal of Population, 1(4), 313-335.

- Sharma, N., \& Patterson, P. G. (2000). Switching costs, alternative attractiveness and experience as moderators of relationship commitment in professional, consumer services. International journal of service industry management, 11(5), 470-490.

- $\quad$ Shields, G. M., \& Shields, M. P. (1989). The emergence of migration theory and a suggested new direction. Journal of Economic Surveys, 3(4), 277-304.

- $\quad$ Sizer, L. M., \& Smith, E. A. (1972). Toward an Integration of Migration and Location Theory.

- $\quad$ Speare, A. (1974). Residential satisfaction as an intervening variable in residential mobility. Demography, 11(2), 173-188.

- Stimson, R. J., \& Minnery, J. (1998). Why people move to the'sun-belt': A case study of long-distance migration to the Gold Coast, Australia. Urban Studies, 35(2), 193-214.

- Thomas, J. S., Blattberg, R. C., \& Fox, E. J. (2004). Recapturing lost customers. Journal of Marketing Research, 41(1), 31-45.

- Trlin, A. D. (1976). Toward the Integration of Factors affecting Immigrant IntraUrban Residential Patterns. New Zealand Geographer, 32(1), 56-89.

- Turkish Electricity Generation Company (2013). Elektrik Üretim Sektör Raporu 2012.

- Turkish Energy Markets Regulatory Authority (2012). Turkish Energy Market:An Investor's Guide

- VaasaETT (2012a). European Residential Energy Price Report: Christophe Dromacque.

- VaasaETT (2012b). World energy retail market rankings. Customer switching research project, Helsinki: Lewis P. E., Brennan S., Kennedy D., Dromacque C. 
- Walsh, G., Dinnie, K., \& Wiedmann, K. P. (2006). How do corporate reputation and customer satisfaction impact customer defection? A study of private energy customers in Germany. Journal of Services Marketing, 20(6), 412-420.

- Walsh, G., Groth, M., \& Wiedmann, K. P. (2005). An examination of consumers' motives to switch energy suppliers. Journal of Marketing Management, 21(3-4), 421-440.

- White, L., \& Yanamandram, V. (2007). A model of customer retention of dissatisfied business services customers. Managing Service Quality: An International Journal, 17(3), 298-316.

- Wolpert, J. (1966). Migration as an adjustment to environmental stress. Journal of Social Issues, 22(4), 92-102.

- Ye, C., \& Potter, R. (2011). The role of habit in post-adoption switching of personal information technologies: an empirical investigation. Communications of the Association for Information Systems, 28(1), 585-610.

- Zeithaml, V. A. (1988). Consumer perceptions of price, quality, and value: a means-end model and synthesis of evidence. The Journal of marketing, 2-22.

- Zeithaml, V. A., Berry, L. L., \& Parasuraman, A. (1996a). The behavioral consequences of service quality. the Journal of Marketing, 31-46.

- Zeithaml, V. A., Bitner, M. J., \& Gremler, D. D. (1996b). Services Marketing McGraw Hill. New York.

- Zengyan, C., Yinping, Y., \& Lim, J. (2009). Cyber migration: An empirical investigation on factors that affect users' switch intentions in social networking sites. In System Sciences, 2009. HICSS'09. 42nd Hawaii International Conference on (pp. 1-11). IEEE.

- Zhang, K. Z., Cheung, C. M., \& Lee, M. K. (2012). Online service switching behavior: The case of blog service providers. Journal of Electronic Commerce Research, 13(3), 184-197.

- Prime Ministry Privatization Administration (n. d.). Date retrieved: 12.05.2015, address: http://www.oib.gov.tr/tedas/tedas.htm 


\section{APPENDIX}

Table 2: Studies that include service quality as a switching factor

\begin{tabular}{|c|c|}
\hline switching attitude & service quality | B2C: Bansal (1997), Bansal and Taylor (1999) \\
\hline switching intention & $\begin{array}{l}\text { service quality I B2C: Anton et al. (2007), Babu (2014) B2B \& C: Zeithaml et. al. (1996a) } \\
\text { service failure | critical incident B2C: Anton et al. (2007) }\end{array}$ \\
\hline switching decision & product quality | B2C: Kim (2008) \\
\hline switching behaviour & $\begin{array}{l}\text { service quality | B2C: Clemes et al. (2010) service failure | B2C: Colgate and Hedge (2001), } \\
\text { Gerrard and Cunningham (2004), reactional triggers B2C: Roos and Gustafsson (2007), core } \\
\text { service failure B2C: Keaveney (1995) service recovery I B2C: Colgate and Hedge (2001), } \\
\text { Colgate and Lang (2001), response in service failure B2C: Keaveney (1995), service } \\
\text { encounter failures B2C: Keaveney (1995) breadth of services I B2C: relationship breadth, } \\
\text { number of subscriptions }{ }^{1} \text { B2C: Abdelrahmamn (2011), range of goods B2C: Roos (1999), } \\
\text { value added services B2C: Makwana et al. (2014), service attributes (C) }{ }^{2} B 2 C \text { : Lewis and } \\
\text { Soureli (2006) convenience I inconvenience B2C: Keaveney (1995), Gerrard and } \\
\text { Cunningham (2004) number of bank branches B2C: distance B2C: Clemes et al. (2010) } \\
\text { location B2C: Roos (1999) }\end{array}$ \\
\hline behavioral intention & service quality B2C: Cronin et al. (2000) B2B: Schertzer (2006) \\
\hline loyalty & $\begin{array}{l}\text { service quality B2C: De Ruyter et al. (1998), Mittal and Lassar (1998), Bloemer et al. } \\
\text { (1999), Aydin and Ozer (2004), Lewis and Soureli (2006) B2B: Lam and Burton (2006), } \\
\text { Caceres and Paparoidamis (2007) relationship quality I service quality B2B: Rauyruen \& } \\
\text { Miller (2007) quality of teaching }{ }^{3} \text { B2C: Hennig-Thurau et al. (2001) call quality B2C: Kim } \\
\text { and Yoon (2004) service failure I B2C: Buttle and Burton (2002) service recovery | B2C: } \\
\text { Buttle and Burton (2002) service attributes (C) }{ }^{4} \text { B2C: Lewis and Soureli (2006) } \\
\text { Convenience I service attributes (B) }{ }^{3} \text { B2C: Lewis and Soureli (2006) }\end{array}$ \\
\hline $\begin{array}{l}\text { repurchase } \\
\text { intentions }\end{array}$ & $\begin{array}{l}\text { service quality I B2C: Cronin and Taylor (1992) service recovery I B2B: White and } \\
\text { Yanamandram (2007) }\end{array}$ \\
\hline Intention to stay & service quality $B 2 B$ : Lam et al. (2009) \\
\hline reasons to stay & service recovery | $B 2 C$ : Colgate et al. (2007) \\
\hline retention & relationship breadth B2C: Gustafsson et al. (2005) \\
\hline
\end{tabular}

\footnotetext{
${ }^{1}$ terms belong to banking industry

${ }^{2}$ Service attributes have measures covering a number of separate constructs representing $(A)$ communication, (B)convenience, and (C)innovative products

${ }^{3}$ terms belong to education sector

${ }^{4}$ Service attributes have measures covering a number of separate constructs representing $(A)$ communication, (B)convenience, and (C)innovative products
} 
Table 3: Studies that include prior switching behavior as a switching factor

\begin{tabular}{|l|l|}
\hline Switching behaviour & prior switching behavior | B2C: Thomas et al. (2004) \\
\hline Loyalty & $\begin{array}{l}\text { prior switching behavior | B2C: Ganesh et al. (2000) } \\
\text { Lam length of business relationship | B2B: }\end{array}$ \\
\hline Retention & prior churn | B2C: Gustafsson et al. (2005) \\
\hline
\end{tabular}

Table 4: Studies that include satisfaction as a switching factor

\begin{tabular}{|l|l|}
\hline Switching intention & $\begin{array}{l}\text { satisfaction | B2C: Bansal (1997), Bansal and Taylor (1999), Walsh et al. (2005), Walsh et } \\
\text { al. (2006) }\end{array}$ \\
\hline Switching behaviour & satisfaction | B2C: Keaveney and Parthasarathy (2001) ${ }^{7}$, Kim and Yoon (2004) \\
\hline Behavioral intention & satisfaction | B2C: Cronin et al. (2000) \\
\hline Loyalty & $\begin{array}{l}\text { satisfaction | B2C: Rust and Zahorik (1993), Jones and Sasser (1995), Gremler and Brown } \\
\text { (1996), Mittal and Lassar (1998), Oliver (1999), Beerli et al. (2004), Buttle and Burton } \\
\text { (2002), Hennig-Thurau et al. (2001), Ball et al. (2004), Kim et al. (2004), Aydin et al. } \\
\text { (2005), Lewis and Soureli (2006), Eshghi et al. (2007), Li and Petrick (2008), Lai et al. } \\
\text { (2009), Ibáñez et al. (2006), Hartmann and lbanez (2007) B2B: Lam et al. (2004) } \\
\text { satisfaction (in relationship quality) B2B: Rauyruen \& Miller (2007) relationship } \\
\text { satisfaction | B2B: Caceres and Paparoidamis (2007) }\end{array}$ \\
\hline Repurchase intentions & $\begin{array}{l}\text { satisfaction | B2C: Cronin and Taylor (1992), Jones (1998 B2B: Patterson and Spreng } \\
\text { (1997) }\end{array}$ \\
\hline Repurchase behavior & satisfaction | B2B: Molinari et al. (2008) \\
\hline Retention & satisfaction | B2C: Gustafsson et al. (2005) \\
\hline
\end{tabular}

Table 5: Studies that include value as a switching factor

\begin{tabular}{|l|l|}
\hline Behavioral intention & value | B2C: Cronin et al. (2000) \\
\hline Loyalty & $\begin{array}{l}\text { value | B2C: Buttle and Burton (2002), Chiu et al. (2004), Lewis and Soureli (2006), Lai et } \\
\text { al. (2009) B2B: Lam et al. (2004) }\end{array}$ \\
\hline Repurchase intentions & value | B2B: Patterson and Spreng (1997) \\
\hline Repurchase behavior & value | B2B: Molinari et al. (2008) \\
\hline
\end{tabular}

\footnotetext{
${ }^{5}$ Authors study the the probability of a firm reacquiring a customer according to the lapse duration

${ }^{6}$ Authors don't directly mention the related construct as a factor, but group customers accordingly and identify their differences

${ }^{7}$ Authors don't directly mention the related construct as a factor, but group customers accordingly and identify their differences
} 
Table 6: Studies that include trust as a switching factor

\begin{tabular}{|l|l|}
\hline switching behaviour & reputation | B2C: Clemes et al. (2010) ethical problems | B2C: Keaveney (1995) \\
\hline loyalty & $\begin{array}{l}\text { trust | B2C: Ball et al. (2004), Aydin \& Özer (2004), Aydin et al. (2005), Lewis \& Soureli } \\
\text { (2006), Ibáñez et al. (2006) B2B: Caceres \& Paparoidamis (2007) brand trust | B2C: } \\
\text { Hartmann and Ibanez (2007) confidence benefits | B2C: Hennig-Thurau et al. (2001) trust } \\
\text { (in relationship quality) B2C: Hennig-Thurau et al. (2001) B2B: Rauyruen \& Miller (2007) }\end{array}$ \\
\hline $\begin{array}{l}\text { anticipated future } \\
\text { interaction }\end{array}$ & $\begin{array}{l}\text { trust of supplier | B2B: Doney and Cannon (1997) trust of sales- person | B2B: Doney and } \\
\text { Cannon (1997) }\end{array}$ \\
\hline reasons to stay & confidence | B2C: Colgate et al. (2007) \\
\hline
\end{tabular}

Table 7: Studies that include commitment as a switching factor

\begin{tabular}{|l|l|}
\hline switching intention & commitment | B2C: Anton et al. (2007) \\
\hline loyalty & $\begin{array}{l}\text { commitment I B2C: Hennig-Thurau et al. (2001) B2B: Caceres and Paparoidamis (2007) } \\
\text { emotional commitment (in relationship quality) I B2C: Hennig-Thurau et al. (2001) } \\
\text { commitment (in relationship quality) I B2B: Rauyruen \& Miller (2007) }\end{array}$ \\
\hline retention & commitment | B2C: Gustafsson et al. (2005) \\
\hline
\end{tabular}

Table 8: Studies that include attitude and subjective norms as a switching factor

\begin{tabular}{|l|l|}
\hline switching attitude & subjective norms B2C: Bansal (1997), Bansal and Taylor (1999) \\
\hline switching intention & $\begin{array}{l}\text { attitude towards switching / subjective norms B2C: Bansal (1997), Bansal and Taylor } \\
(1999)\end{array}$ \\
\hline
\end{tabular}

Table 9: Studies that include influential triggers as a switching factor

\begin{tabular}{|l|l|}
\hline Switching behaviour & $\begin{array}{l}\text { influential triggers | B2C: Roos and Gustafsson (2007) advertisement | B2C: Clemes et al. } \\
(2010)\end{array}$
\end{tabular}

Table 10: Studies that include price as a switching factor

\begin{tabular}{|l|l|}
\hline switching attitude & expected economic benefits | B2C: Gamble et al. (2009) \\
\hline switching intention & price changes | B2C: Anton et al. (2007) \\
\hline switching decision & price | B2C: Kim (2008) \\
\hline switching behaviour & $\begin{array}{l}\text { price | B2C: Roos (1999), Thomas et al. (2004), Clemes et al. (2010) pricing | B2C: Keaveney } \\
\text { (1995), Gerrard and Cunningham (2004), Makwana et al. (2014) pricing problems | B2C: } \\
\text { Colgate and Hedge (2001) interest rate }\end{array}$ \\
\hline loyalty & price | B2B: Naumann et al. (2010) \\
\hline
\end{tabular}

\footnotetext{
${ }^{8}$ terms belong to banking industry
} 
Table 11: Studies that include alternative attractiveness as a switching factor

\begin{tabular}{|l|l|}
\hline Switching behaviour & $\begin{array}{l}\text { attraction by competitors | B2C: Keaveney (1995) apathy (B) } \\
(2001)\end{array}$ \\
\hline Loyalty & $\begin{array}{l}\text { quality of alternative options I B2C: Li and Petrick (2008) better service | B2B: Naumann } \\
\text { et al. (2010) }\end{array}$ \\
\hline Repurchase intentions & attractiveness of alternatives | B2B: White and Yanamandram (2007) \\
\hline Reasons to stay & alternatives | B2C: Colgate et al. (2007) \\
\hline
\end{tabular}

Table 12: Studies that include segment focus as a switching factor

\begin{tabular}{|l|l|l|}
\hline Behavioral intention & $\begin{array}{l}\text { image - industry knowledge | B2B: Schertzer (2006) image - customer focus and expertise | } \\
\text { B2B: Schertzer (2006) }\end{array}$
\end{tabular}

Table 13: Studies that include variety seeking as a switching factor

\begin{tabular}{|l|l|}
\hline Switching behaviour & variation B2C: Roos (1999) \\
\hline Repurchase intentions & inertia (B) ${ }^{\mathbf{1 0}}$ B2B: White and Yanamandram (2007) \\
\hline
\end{tabular}

Table 14: Studies that include switching costs as a switching factor

\begin{tabular}{|l|l|}
\hline switching attitude & information search costs | B2C: Gamble et al. (2009) \\
\hline switching decision & switching costs I B2C: Kim (2008) \\
\hline $\begin{array}{l}\text { switching } \\
\text { behaviour }\end{array}$ & $\begin{array}{l}\text { switching costs I B2C: Kim (2008), Matthews et al. (2008) } \\
\text { investment (A) Clemes et al. (2010) relationship } \\
\text { Abdel-rahmamn (2011) apathy (A) }{ }^{14} \text { | B2C: Colgate and Lang (2001) negativity | B2C: Colgate } \\
\text { and Lang (2001) }\end{array}$ \\
\hline $\begin{array}{l}\text { loyalty } \\
\text { repurchase } \\
\text { intentions }\end{array}$ & $\begin{array}{l}\text { Aydin and Özer (2004), Aydin et al. (2005), Ibáñez et al. (2006), Hartmann and Ibanez (2007 } \\
\text { B2B: Lam et al. (2004) investment in the relationship | B2C: Li and Petrick (2008) }\end{array}$ \\
\hline
\end{tabular}

\footnotetext{
${ }^{9}$ Apathy has two measures; (A) relating to switching costs and (B) relating to attractiveness of alternatives

${ }^{10}$ White and Yanamandram (2007) define two dimensions of inertia: "(A) Inertia as the outcome, the customer thinks that the alternatives are unattractive due to switching costs), (B) Inertia as a behavioural characteristic defined as "the customer is lazy, inactive, or passive"

${ }^{11}$ Matthews et al. (2008) found out that "switching costs on the relationship between a person's desire to switch banks and the likelihood that they will actually do so", however in the table it is located under switching behaviour column for the sake of the presentation

${ }^{12}$ Relationship investment has two parts of measures; A relating to switching costs and B relating to social bonds

${ }^{13}$ terms belong to banking industry

${ }^{14}$ Apathy has two measures; (A) relating to switching costs and (B) relating to attractiveness of alternatives

${ }^{15}$ White and Yanamandram (2007) define two dimensions of inertia: "(A) Inertia as the outcome, the customer thinks that the alternatives are unattractive due to switching costs), (B) Inertia as a behavioural characteristic defined as "the customer is lazy, inactive, or passive"
} 


\begin{tabular}{|l|l|}
\hline retention & switching costs | B2C: Hess and Ricard (2003) \\
\hline reasons to stay & switching costs | B2C: Colgate et al. (2007) time and effort |B2C: Colgate et al. (2007) \\
\hline
\end{tabular}

Table 15: Studies that include social bonds as a switching factor

\begin{tabular}{|l|l|}
\hline switching intention & relational bonds | B2B: Lam et al. (2009) \\
\hline switching behaviour & relationship investment (B) ${ }^{16}$ I B2C: Colgate and Lang (2001) \\
\hline loyalty & $\begin{array}{l}\text { Inter-personal bonds | B2C: Gremler and Brown (1996) special treatment | B2C: Gremler } \\
\text { and Brown (1996) special treatment benefits I B2C: Hennig-Thurau et al. (2001) social } \\
\text { benefits | B2C: Hennig-Thurau et al. (2001) personnel | B2C: Roos (1999) }\end{array}$ \\
\hline repurchase intentions & interpersonal relationships B2B: White and Yanamandram (2007) \\
\hline reasons to stay & social bonds | B2C: Colgate et al. (2007) emotional bonds B2C: Colgate et al. (2007) \\
\hline
\end{tabular}

Table 16: Studies that include image as a switching factor

\begin{tabular}{|l|l|}
\hline Loyalty & $\begin{array}{l}\text { image | B2C: Lewis and Soureli (2006) brand image | B2C: (Kim and Yoon (2004) corporate image I B2C: } \\
\text { Aydin and Özer (2004) }\end{array}$
\end{tabular}

${ }^{16}$ Relationship investment has two parts of measures; A relating to switching costs and B relating to social bonds 